\title{
Juvenile Delinquency in Accessing Pornography Through Social Media in the City of Singaraja
}

\author{
Ni Putu Rai Yuliartini ${ }^{1}$, M. Jodi Setianto ${ }^{2}$ \\ \{raiyuliartini@undiksha.ac.id,jodi.setianto@undiksha.ac.id\} \\ Universitas Pendidikan Ganesha ${ }^{1}$, Universitas Pendidikan Ganesha ${ }^{2}$
}

\begin{abstract}
The purpose of this study was to determine the factors that cause children to be addicted to accessing pornography, as well as the efforts to overcome them by law enforcers. This research is empirical legal research, where the data sources come from primary and secondary data. The data processing and analysis were carried out qualitatively, in which the overall results of the data analysis were presented descriptively and explained in full about the problem. The results showed that, based on the Containment theory put forward by Walter C. Reckless, it appears that the factors that cause children to be addicted to accessing pornography are divided into 2 (two) namely internal factors and external factors. Which later, if these factors cannot be controlled properly, it will become negative behavior. Furthermore, it also explains the countermeasures carried out by related parties, namely in the form of preemptive, preventive, or repressive efforts.
\end{abstract}

Keywords: Juvenile delinquency; access to pornography; prevention

\section{Introduction}

The increasingly rapid development of information technology, coupled with the pretext of the community to know each other and communicate with each other, makes the life of these people have a sense of connection and mutually complementary to developments in information technology within the community itself. One result of technological advances that have been created is the internet. The internet (international network) is a very large computer network consisting of small networks that are interconnected and span the entire world [1]. In today's millennial era, there are many breakthroughs in existing technology devices by relying on the internet network as a distribution medium and socializing easily through features in the media called social media and can be easily accessed by the various groups including children and adolescents.

Adolescents belonging to the millennial generation tend to be more adaptive to the development of communication technology. This is because they were born and grew during the very rapid development of communication technology and the increasing level of use of digital technology and the internet. But on the other hand, the development of digital social media cannot be separated from negative impacts [2].One of them is related to the production, distribution, and consumption of pornographic content. Therefore, it is not surprising that every 
day a lot of news pops up about cases about the number of adolescent who very easily access the content. It can be said that Indonesia is in an emergency with the dangers of pornographic content, both through printed media such as magazines and electronic media.

The development of pornography which is increasingly prevalent cannot be separated from the development of communication technology today. Pornographic content, which was originally distributed via the Digital Versatile Disk (DVD) or Versatile Compact Disk (VCD), can now be accessed easily via laptops, tablets, smartphones, and other digital devices supported by an internet connection. Various features and designs are offered by smartphones, which in the end become a special attraction among the community, including among children or adolescents.

Among various age categories or generations, adolescent are vulnerable to negative access to smartphone use. This is due to his immature psychological development. They can intentionally or unintentionally be easily exposed to pornographic content via smartphones. This is because adolescent who are teenagersare the age at which a child is looking for and forming their own identity [3]. Accessing pornography on social media via the internet is a "prohibited act" and the regulation is contained in positive law in effect in Indonesia. This is regulated in Undang-Undang Nomor 19 Tahun 2016 concerning amendments to Undangundang Nomor 11 Tahun 2008 concerning Electronic Information and Transactions (later called the ITE Law) [4].

We have encountered this kind of delinquency in big cities and have even started to mushroom in small cities in every province. The place where the researchers conducted the research was in Singaraja City, which is part of the Buleleng Police jurisdiction. The reason the researchers researched in Singaraja City is that Singaraja is the capital and administrative area of the Buleleng Regency which is located in the north of Bali Island, which is known as "City of Education and Knowledge". This was marked by the inauguration of new branding, namely "Singaraja, The City of Science". Singaraja City as an Education City should be a city that organizes a comprehensive and equitable aspect of education for all parties, so that the community, especially adolescents, can enjoy the services provided by the Buleleng Regency government. Singaraja City, which is a city of education, is followed by the development of the world of technology as a means of supporting the implementation of education for children and adolescents which is useful to facilitate and assist them in learning or making assignments, but on the contrary is used as a forum to access pornographic matters, especially in cyberspace.

Various cases of juvenile delinquency that have occurred have caused fear and concern in the community. Activities that often occur in Singaraja City related to pornography in cyberspace (the internet) are the number of adolescents who like to access by viewing pornographic sites such as sex images, sex stories, as well as storing activities, providing sexrelated data, or exhibiting or uploading vulgar videos and photos on social media such as Facebook, Instagram or YouTube.

One example of case related to juvenile delinquency in accessing pornography on social media is the circulation of naked photos of junior high school students (one of the public schools in Singaraja City) on social media [5]. Besides, because of the frequent activities of accessing pornography on the internet, it can have a negative impact and impact on the development of these children. So that the serious impact that has occurred due to accessing pornographic videos is that some young people (teenagers) have the heart to rape students who are still in junior high school, because of the influence of previously watched porn videos [6]. 
Based on the conceptual analysis and empirical conditions as described above, it has strategic value to be studied. Given that deviant behavior is breaking the law, it is a serious problem in the development of children towards their future, especially if these children are not provided with sufficient sex education for them. This complex problem cannot be put on the shoulders of the teachers alone, but there is a cooperation between parents, school principals, and law enforcement officials to deal with these problems. Judging from the problems that exist in Singaraja City, countermeasures are needed through penal or non-penal facilities from law enforcement officialsto prevent students (teenagers) from deviant behavior.

Based on the above explanation, several problems can be formulated, namely: what factors cause children (adolescents) to access pornography through social media in Singaraja City, as well as what countermeasures can be done by law enforcement officials in reducing the number of child addictions, Adolescents in accessing pornography through social media in Singaraja City.

\section{Methods}

In this study, the method used is legal research in empirical studies, by looking at law as a reality that includes social, cultural, and other realities (examining law in action) [7]. This research is descriptivewhich aims to describe something in a certain area and at a certain time [8]. The research location chosen was Singaraja City. So that in this study the data used are primary data and secondary data, which data collection uses interview techniques, document study and observation. The technique of determining the research sample used purposive sampling, and the data analysis technique was carried out qualitatively.

\section{Result and Discussion}

\section{Factors that cause adolescents to access pornography through social media in Singaraja}

The In the current era of globalization, social media is made one of the primary needs by the wider community, where everything can be found only with a cellphone. The advancement of technology is not only felt by the elitebut for all people, both old and young, even teenagers who still tend to have shaky emotions and can be influenced by the outside world. The technology devices provided by the current era are made so easy and varied for its users, especially application features related to social media. Even young children are very easy to learn about the use of technological devices that are widely used by adults. And the impact of social media can be positive or negative depending on how it is used.

According to Undang-Undang Sistem Peradilan Pidana Anak Nomor 11 Tahun 2012 [9], it is stated in Article 1 paragraph (3) which reads "Children in conflict with the law, here in after referred to as Children, are children who have reached the age of 12 (twelve) years, but have not reached the age of 18 (eight). fifteen) years who were suspected of committing a criminal offense "Nowadays children are one of the groups that have a big interest in the use of social media so that the use of social media is often used for negative things which later lead them to a bad life. As is the case today, the Covid-19 Pandemic which requires school adolescents to learn from home using electronic media, so the role of parents is very much needed to monitor the child's daily life in using electronic media. However, due to the busyness 
experienced by the children's parents, it has resulted in negligence in supervising the child, which causes the child to freely access content that is not old enough for them to watch, one of which is adult content or pornography.

Pornography is one of the issues that is still hot to be discussed by the wider community, ever since the emergence of the Anti-Pornography and Porno-Action Law (later called the Anti-Pornography Law) in early 2006. The Anti-Pornography Law defines pornography as images, sketches, illustrations, sounds, sounds, moving images, animation, cartoons, conversations, gestures, or other forms of messages through various forms of communication media and/or public performances that contain obscenity or exploitation. sex that violates the norms of decency in the society. Until now, many teenagers like to access pornography wherever they were.

The phenomenon of adolescents who like to access pornography on social media is not new to society, one of which is in Singaraja City. For the community, this delinquency is a social problem that has existed for a long time. This is what makes parents or law enforcers nervous about children's behavior today.

Responding to adolescents who like to access pornographic content in Singaraja City, it makes us sad or sad to hear about it. Young people who are supposed to do positive and useful activities to fill their spare time and prepare for learning, tend to be more interested in accessing pornographic content. As a result, without the child realizing/knowing it, accessing pornography can have a very fatal impact, includinga) encouraging children to imitate sexual acts, b) forming negative attitudes, values, and behavior, c) causing difficulty concentrating while studying, d) closed, inferior and not confident.

Seeing the serious impact that has occurred, of course, it becomes a big question, what was the reason for them to take this reckless and dangerous action. From the results of research that has been conducted in Singaraja City, in general, there are 6 (six) factors that cause the child to be addicted to accessing pornographic content. These factors include: 1) peer influence, 2) technological sophistication, 3) family factors, 4) environmental influence, 5) curiosity, 6) unable to take advantage of free time.

If viewed from the containment theory, which is one of the theories in analyzing problems related to the factors of adolescents accessing pornography on social media above, containment theorystates that individuals already have various social controls (containment) which will help in fighting pressure. - the pressure that draws young children to crime. As emphasized by Walter C. Reckless (1961) with the help of Simon Dinitz, containment theory explains that there are several ways of defense for individuals to act following the values and norms that live and apply in society. Self-defense in this theory, there are 2 (two), namely internal (inter) and external (outer).

The basic elements of containment theory by Reckless, can be seen as follows [10].

1) Layers of Social Pressures

a. External Pressure, encouraging someone to commit a crime. Variables that influence a person to commit a crime include: poor living conditions, adverse economic conditions, members of minority groups, and lack of reasonable opportunities;

b. Externalpulls, pulling an individual away from social norms and pressed from the absence of bad friends, a distorted subculture, and the influence of the media; 
c. Internal pressure, encourage someone to do evil, they include personal tensions, feelings of inferiority or inadequacy, mental conflicts, organic depravity, and the like.

\section{2) Containments}

Inner containments, refers to the internalization of conventional behavioral values, and the development of personality traits that enable a person to resist these pressures; and outer containments, represented by an effective family and support system that is closely involved in helping to uphold conventionality and isolate the individual from attacks by outside pressure. Based on the explanation of the containment theory above, we can see that adolescents can commit delinquency or deviance because it is caused by the extent to which the forces of internal factors (such as needs to be met, anxiety, cruelty) and external (such as poverty, unemployment) can be found. control by one's outer containment and inner containment.

Furthermore, the author will classify the six factors that cause children to access pornography in Singaraja City into internal and external factors, along with a description of the analysis related to containment theory. First, The factors that are included in the internal factors that cause adolescents to access pornography are 1) curiosity from within themselves, and 2) unable to take advantage of free time. (1) Self-curiosity; Self-curiosity is one of the factors causing adolescents to become addicted to accessing pornography, which is an internal factor. Why is that? because it begins with excessive curiosity so that it creates an urge to curiosity to try and open pornographic content on social media. The growing interest in accessing pornography grows from within, so we will always seek information from the internet about pornography in the form of videos, pictures, and others. (2) Cannot Take Advantage of Free Time. The results of interviews with respondents as a whole, they said that after school activities ended, they would have free time to do things they like through social media. Especially now that the Covid-19 Pandemic makes adolescents learn from home and live full of activities on the internet network. So that adolescents have a great opportunity to do things that are negativeand especially men, they will take advantage of this free time to access pornography. They cannot take advantage of the available free time to create positive activities related to task development from online learning or self-development. Second, External Factors, Apart from the internal factors described above,several factorscause children to become addicted to accessing pornography, namely those from outside / externally. These factors include: 1) peer influence, 2) technological sophistication, 3) family factors and 4) environmental influence. The following is an explanation of the factors that cause adolescents to be addicted to accessing pornography that comes from outside of these adolescents.

Looking at the causal factors above, adolescents who access excessive pornographic content eventually take action, because they lack the strength to resist the temptation not to take action that violates the norms of positive law (in this case the ITE Law and the AntiPornography Law) in force. In addition to the weak self-control of the individual perpetrator, this delinquency also occurs due to the lack of understanding of the child or adolescent about the consequences or impacts that can be caused by the actions they do. Conditions like this clearly show that the defense and self-control from within the child as a child whose hobby is accessing pornographic content is at a low point. So that it takes a harder effort to make 
improvements or countermeasures against this, which in turn can minimize these teenagers from accessing pornographic content.

Overcoming efforts carried out by law enforcement officials in reducing the addiction rate of teenagers in accessing pornography through social media in Singaraja City

At present, pornographic content has become the favorite content of most young people in Indonesia. They do not know about the dangers of pornography which can make them regret in the future because they often access pornography. Lack of knowledge or education about the dangers of pornography and sexual education is one of the reasons children continue to access pornography on social media and it has even become a new habit to fill their spare time. For that, we need several efforts to overcome this.

Efforts to combat crime are continuous and continuous efforts that are always there, in fact, there will never be any final efforts. These efforts were made to ensure the protection and welfare of the community [11]. So is the case with the efforts made in overcoming juvenile delinquency in accessing pornography on social media. The role of the family is very necessary for it because parents are more intensively connected with the cadolescents themselves. However, the role of parents is not sufficient to tackle delinquency in adolescents who access the internet, but cooperation with related parties, in this case, is the Police, Social Service and the Office for Population Control, Family Planning, Women's Empowerment and Child Protection, so that these children can break bad habits of accessing pornography on social media. Because as has been discussed in the previous chapter, this delinquency can have a bad impact on the younger generation who are around it in particular.

Based on the results of the author's research, the prevention efforts for adolescents who like to access pornography in Singaraja City are as follows. Providing education, through conventional efforts, namely in the form of socialization as well as providing explanations and understanding to the public, in this case,adolescents, to avoid the spread of pornographic content as regulated in the ITE Law. During the socialization, information was conveyed about the importance of knowing the substance of the ITE Law, one of which is the prohibition of the dissemination of pornographic content because this will be legally processed. This socialization is carried out by the Police in collaboration with other government agencies, and also especially with schools as the environment and facilitators for the Police to convey information.

Provide understanding to the public directly at the police station for adolescents who have violated the ITE Law. For students who have violated by spreading pornographic content, the police will use a persuasive / individual approach to educate them intensively so that they do not repeat the actions related to violations of the ITE Law. After taking an individual approach, then briefing was also given to the parents of the students. Then the police also conducted outreach to the villages regarding the prohibition of accessing pornography. If all of the above cannot be resolved by means of an individual approach, then it can then be processed legally through a court which aims to provide a deterrent effect (ultimumremedium).

Supervise or monitor through the Cyber Patrol Web orsocial media. Besides, the police also provide various campaigns related to ITE content that must be obeyed, one of which is related to the distribution of pornographic content. Implementation is carried out through a social media campaign, namely providing information about the prohibition of the distribution 
of content on social media that violates the ITE Law, one of which is pornographic content. This is done by spreading various posters and written information through the cyber patrol web, and also on various official media accounts of the Buleleng Police such as Facebook, Instagram, and other social media.

Apart from the Buleleng Police, there are also related agencies that are making countermeasures, namely the Buleleng Regency Social Service. The efforts that have been made in overcoming an addiction to accessing pornographic content are preventive or preventative measures. To prevent it, the Indonesian Ministry of Social Affairs has a program called the PEKSOS Goes To School program or abbreviated as PGTS. This program is implemented 2 times a year. The PGTS program itself has several themes that are raised from the social problems of adolescents and children in general, one of which is pornography. This program is carried out by collaborating with several schools that have visited and conducted socialization related to pornography, regulations related to pornography such as the AntiPornography Law, and the impact that pornography can have both psychologically, especially on children's mental and also physical impacts such as doing activities inappropriate, for example, masturbation and so on.

The Buleleng Regency Social Service, has held several meetings and participated in various socializations with several related parties, both from the Ministry of Communication and Information, Center Police Officer, Psychologists, Psychiatrists, Social Affairs, and Social work. In the results of the last meeting related to the prevention of pornographic content that can damage the mental and psychological damage of adolescents, the Social Service together with related agencies tried to block pornographic sites that were still freely accessible to teenagers. In addition to blocking these pornographic sites, the social service also assists by helping the child consult a child psychologist, who will later try to overcome the addiction. Because as we all know, that one of the causes of addiction is also due to a child's curiosity, which is generally very large, although not fully children can accept the content. The social service collaborates with several child psychologists from other agencies to help reduce children's addiction from this content, and also collaborates with the child's parents to help monitor what the child has access to. Even though the social service has made various efforts, there are still several other efforts that still need to be done, because to reduce the effects of this addiction it takes time and a process that is not short, it takes several meetings and also requires intervention from psychologists in some of these meetings.

Apart from the social service, the Buleleng District Population Control, Family Planning, Women's Empowerment and Child Protection Agency has also made efforts to reduce the number of addictions of children in accessing pornography by implementing the GENAKSA (Gerakan Nasional Anti Kekerasan Seksual Anak) program. This program is implemented by conducting socialization to schools and also in collaboration with the Education Office.

\section{Conclusion}

Based on the research results that have been described in the previous chapters, it can be concluded that: The factors that cause adolescents to access pornography in Singaraja City 
include: (a) Internal Factors. Factors included in the internal factors that cause adolescents to be addicted to accessing pornography are the child's inner curiosity, and not being able to take advantage of free time so that it can cause children to access pornography. (b) External Factors. The factors that are included in the external factors that cause adolescents to be addicted to accessing pornography are: 1) the influence of friends at play (peers), 2) technological sophistication causes adolescents to easily access pornography, 3) family factors, 4) environmental influence is also a factor in these adolescents accessing pornography on social media.

\section{References}

[1] B. S. D. Oetomo, Konsep Teknologi dan Aplikasi Internet Pendidikan. Yogyakarta: Andi Offset, 2002.

[2] R. Rachmaniar, P. Prihandini, and P. A. Janitra, "Perilaku Penggunaan Smartphone dan Akses Pornografi di Kalangan Remaja Perempuan,” J. Komun. Glob., vol. 7, no. 1, pp. 1-11, 2018, doi: 10.24815/jkg.v7i1.10890.

[3] S. D. Gunarsah, Dari Anak Sampai Usia Lanjut: Bunga Rampai Psikologi Anak. Jakarta: BPK Gunung Mulia, 2004.

[4] Undang-Undang Republik Indonesia Nomor 19 Tahun 2016 tentang perubahan atas Undang-Undang Nomor 44 Tahun 2008 Tentang Pornografi. Indonesia: UndangUndang Republik Indonesia Nomor 19 Tahun 2016 tentang perubahan atas UndangUndang Nomor 44 Tahun 2008 Tentang Pornografi, Pub. L. No. 19 (2016). https://ngada.org/uu44-2008.htm, 2016.

[5] R. A. A. Desiani, "Foto Tanpa Busana Siswi SMP Buleleng Viral di Media Sosial Halaman all - Tribunnews.com Mobile," Tribunnews.com, 2020. https://m.tribunnews.com/regional/2020/01/22/foto-tanpa-busana-siswi-smp-bulelengviral-di-media-sosial?page=all (accessed Feb. 20, 2020).

[6] "4 Pemuda di Buleleng Menggilir Siswi SMP di Kamar Kos, Diperdaya Pelaku Masih Berseragam Sekolah - Tribun Bali,” Bali Tribunnews.com, 2019. https://bali.tribunnews.com/2019/01/30/4-pemuda-di-buleleng-menggilir-siswi-smpberawal-saat-korban-main-ke-kosan-pelaku (accessed Feb. 20, 2020).

[7] A. Ali and W. Heryani, Menjelajahi Kajian Empiris terhadap Hukum. Jakarta: Kencana Prenada Media Group, 2012.

[8] B. Waluyo, Penelitian Hukum dalam Praktek. Jakarta: Sinar Grafika, 2008.

[9] Undang-Undang Republik Indonesia Nomor 11 Tahun 2012 Tentang Sistem Peradilan Pidana Anak. Indonesia, 2012.

[10] F. E. Hagan, Introduction to Criminology Theories Methods and Criminal Behavior. Chicago: Nelson Hall, 1989.

[11] B. Suhariyanto, Tindak Pidana Teknologi Informasi (Cybercrime) Urgensi Pengaturan dan Celah Hukumnya. Jakarta: PT. Raja Grafindo Persada, 2012. 